\title{
Study of some Hydrolytic Enzymes in Sera and Saliva of Patients with Oral Epithelial Tumors
}

\author{
Hathama R. Hasan \\ Department of Chemistry \\ College of Science \\ Baghdad University
}

\author{
Rukzan M. Dawood \\ Department of Chemistry \\ College of Education for Girls \\ Mosul University
}

(Received 1/8/2010; Accepted 6/12/2010)

\begin{abstract}
The present study was designed to investigate the changes in the activity and specific activity of some hydrolytic enzymes like $\alpha$ - amylase, alkaline and acid RNase in sera and saliva of patients with oral epithelial tumors (benign and malignant). Then follow up the variation of these enzymes using polyacrylamide gel electrophoresis technique to evaluate the changes of these isoenzymes due to the presence of the tumors.

Thirty three patients with oral tumors (benign and malignant) aged from 15-75 years attending the specialized surgery hospital in Baghdad medical city, were included in the present study. Thirty one healthy individuals of matched age and gender were utilized as control. The results indicated the presence of highly significant increase $(\mathrm{P}<0.001)$ of sera alk. RNase activity (U/L) in both benign and malignant groups in comparison to that of control. The specific activity results $(\mathrm{U} / \mathrm{mg})$ showed also a significant increase $(\mathrm{P}<0.05)$ in both benign and malignant groups. The results of acid RNase activity and specific activity reflected a non significant increase in both benign and malignant groups. The salivary amylase activity (U/L) and specific activity $(\mathrm{U} / \mathrm{mg})$ showed significant decrease $(\mathrm{P}<0.001)$ in malignant group, whereas the sera amylase activity and specific activity revealed a non significant increase in both benign and malignant groups.
\end{abstract}

Keywords: saliva, oral cancer, amylase, RNases, tumors 


\section{درلسة فعالية بصن الانزيمات المحالة فمطل و للبل المرض المصلبين بأورلم خلايا الفم اللالائية}

\section{الماذص}

تضمن البهث مناقثة التغيرات في الفعالية والفعالية النوعية لبعض الإنزيمات المحللة مل ه -الميليز و

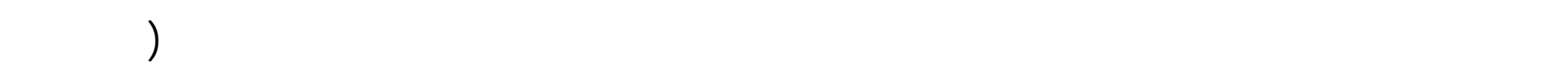

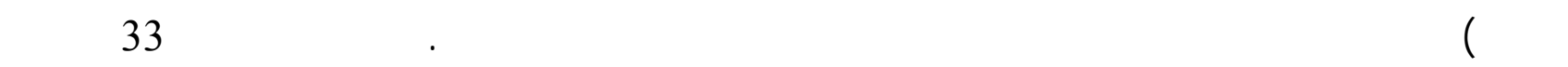

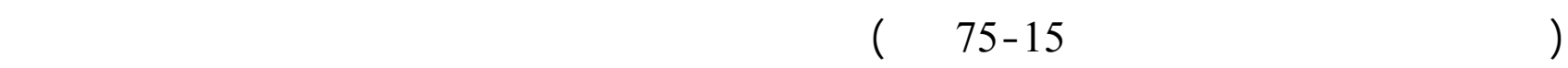
الجرلحلت التخصصية في مدينة بغداد الطبية و31 من الأشخاص الأصحاء (نكور و إنلث بنفس مديلت الأعمار)

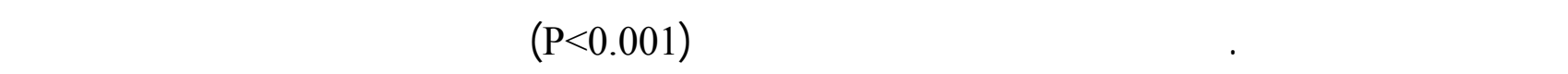

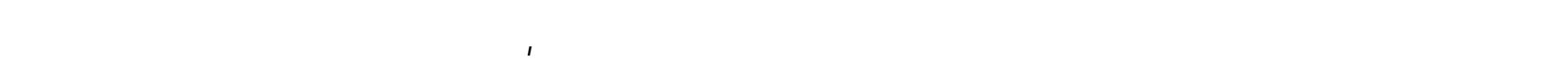

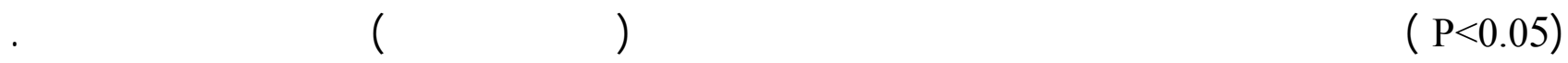

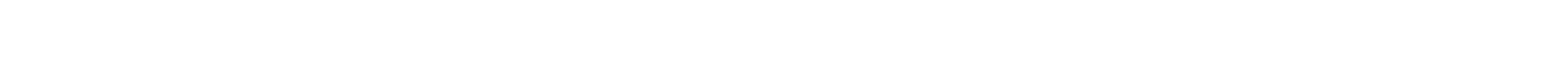

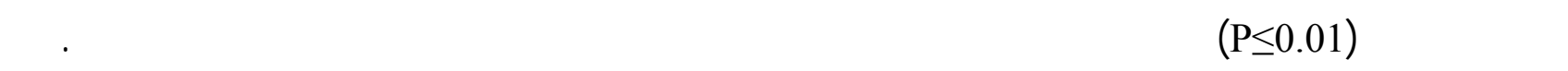

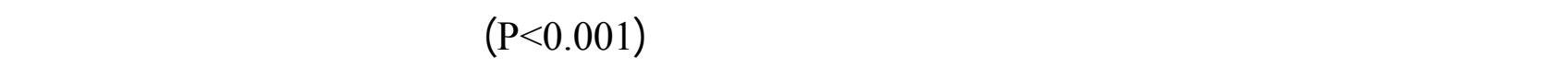
للانزيم في اللعب لمجموعة الاورلم الخبيثة مقارنة بمجموعة الضطب, بينما لم طاهر نتنائج الفعالية و الفعالية

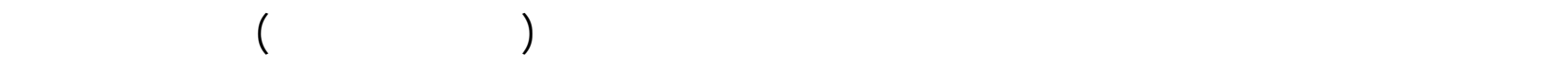
الضط .

\section{الهاملت الدالة: العلب,سرطلن الفم, الميليز, الارينيز, أورلم.}

\section{INTRODUCTION}

Oral cancer is the $6^{\text {th }}$ most common cancer in the world, with a high morbidity rate, and a 5 -years mortality rate of about 50\% (Kantola et al., 2000). Oral cancer is described as an ulcerated lump or sore that may or may not be associated with pain, and often involving the regional lymph nodes (Lac, 2002). Saliva has many diagnostic uses, like large scale screening and epidemiologic studies (Kaufman et al., 2002; Amerongen et al., 2007). Whole saliva is most frequently used for diagnosis of systemic diseases, since it is readily collected and contains serum constituents. These constituents are derived from the local vasculature of the salivary glands and reach the oral cavity via the flow of gingival fluid (Nagler et al., 2006). 
Human salivary alpha amylase is the only enzyme in saliva capable of degrading oligosaccharides. It has been found that amylase accounts for $40-50 \%$ of the total salivary gland-produced protein, mostly synthesized in the parotid gland (Nobel, 2000). Human parotid saliva and submandibular saliva contain about $45 \mathrm{mg}$ and $30 \mathrm{mg}$ of amylase, per $100 \mathrm{mg}$ of protein respectively. It is generally considered to be a reliable marker of serous cell function (Almstahl et al., 2001). Amylase also interacts specifically with certain oral bacteria and may play a role in modulating the adhesion of those species to teeth (Van der Maarel et al., 2002). It has been found that salivary amylase inhibits the growth of Lgionella pneumophila and Neisseria gonorrhoeae (Rantonen, 2003).

Ribonucleases are enzymes catalyze the breakdown of ribonucleic acid (RNA) which is the chemical material in a cell that codes for different proteins (Raines, 1998). Different types of RNase have been reported to be present in human, the most extensively studied one is the bovine pancreatic ribonuclease (or RNase A; EC 3.1.27.5) because of its ease of purification and small size $(14 \mathrm{KDa})$. It catalyzes the cleavage of the P-O bond of RNA on the 3 side of pyrimidine nucleosides (Jianzhi et al., 2003). The structure of RNase A is stabilized by four disulfide bonds that involve all eight of its cysteine residues. Human ribonuclease is widely distributed in various organs, such as the pancreas and body fluids including serum, urine, saliva, and cerebrospinal fluid (Blank, 1989; Jochen, 2006). RNase has been considered as a possible tumor marker for some tumors e.g. pancreatic tumor (Ester et al., 2000), and an elevation level of this enzyme was reported in sera of patient with benign and malignant uterine tumors (Al-Shamarre, 2002).

The aim of the present study was to investigate amylase and RNases activity, and to detect any changes in these enzymes forms both in sera and saliva of patients with benign and malignant oral tumors.

\section{Subjects}

\section{MATERIALS AND METHODS}

Sixty five individuals were included in the present study; thirty three of them were clinically and histologically diagnosed as patients with oral epithelial tumors (benign and malignant). The samples were collected from patients attending the hospital of Specialized Surgery in Baghdad Medical City. Patients were evaluated by full medical history to exclude any existing of systemic disease or taking any drug that may affect the parameters to be examined. The results were compared with those obtained from a control group of thirty one age and gender matched healthy individuals.

\section{Samples}

Sera Samples: Six milliliters of venous blood taken from each individual, collected in plane polyethylene tube, allowed to stand at room temperature for thirty minutes, then samples were centrifuged at $(2000 \mathrm{xg})$ for 10 minutes. The obtained sera transferred immediately to another test tubes. These samples were estimated directly for enzymes activities or frozen at $20{ }^{\circ} \mathrm{C}$ for subsequent analysis. Hemolyzed samples were discarded. 
Saliva Samples: about ten milliliters unstimulated (resting) whole saliva were collected after the diagnosis, under resting conditions between 8.0-10.0 A.M. Patients were asked to rinse their mouth with water and to generate saliva in their mouth and to spit into a wide test tube (Mavazesh, 1993). The collection period was twenty minutes. Following the collection, the saliva was centrifuged at $(2000 \mathrm{xg})$ for 10 minutes. The resulting supernatant was stored at $-20{ }^{\circ} \mathrm{C}$ in polyethylene tubes until assayed.

\section{Determination of protein concentration}

A modified Lowry method by Hartree (Hartree, 1972) was used to determine saliva and serum total protein concentration using BSA (bovine serum albumin) as a standard.

\section{Measurement of $\alpha$ - Amylase Activity}

Amylase activity was measured according to Caraway method (Caraway, 1969). The samples were incubated with buffered starch substrate at controlled temp. $\left(37^{\circ} \mathrm{C}\right)$ for 15 minutes, then subsequently react with iodine to produce a blue color with starch. The decrease in the color compared with that obtained in the absence of amylase (the control), provides a measure of amylase activity.

(Amylase activity unit $/ 100 \mathrm{ml})=\frac{\mathrm{C}-\mathrm{T}}{\mathrm{C}} \times$ conc. of St. $\times$ dilution factor

$\mathrm{T}=$ the absorbance of the test

$\mathrm{C}=$ the absorbance of the control

The specific activity of the enzyme was expressed in U per mg of protein.

\section{Measurement of alkaline RNase activity}

Alkaline RNase was estimated according to Bardon and Shugar method (Bardon, 1980) with the following modification:

A volume of $1 \mathrm{ml}$ of Davis buffer was used. A volume of total reaction mixture was $1.1 \mathrm{ml}$ instead of $0.2 \mathrm{ml}$ reported in the original method.

- Davis buffer ( Davis,1958): The following weights were dissolved in appropriate amounts of distilled water to prepare one liter of the buffer: Citric acid (21.01gm); Potassium dihydrogen orthophosphate (13.61gm); Sodium tetraborate (19.07gm); Tris (hydroxymethyl aminomethane)(12.11gm); and Potassium chloride $(7.46 \mathrm{gm})$. The $\mathrm{pH}$ of the solution was adjusted to (8) using sodium hydroxide $(0.4 \mathrm{~N})$, Note: $0.1 \mathrm{ml}$ of saliva sample was used instead of $0.05 \mathrm{ml}$ of serum.

\section{Measurement of acid RNase activity}

Acid RNase activity was measured as alkaline RNase activity except that the $\mathrm{pH}$ of Davis buffer was adjusted to 5 .

Acid andalkaline RNase activity was expressed as Unit/L.

RNase activity $(\mathrm{U} / \mathrm{L})=(\Delta \mathrm{A} / \mathrm{t} \times \mathrm{Vt} / \mathrm{Vs} \times 1000)$ 


$$
\begin{aligned}
& \Delta \mathrm{A}=\text { Sample's absorbance }- \text { Control's absorbance } \quad(\text { at } \lambda=260 \mathrm{~nm}) \\
& \mathrm{Vt}=\text { the total volume, } \mathrm{Vs}=\text { the volume of the sample (serum, saliva), } \\
& \mathrm{t}=\text { the incubation time }(\mathrm{min})
\end{aligned}
$$

\section{Conventional polyacrylamide gel electrophoresis}

This technique was carried out to analyze sera and saliva samples of the control and benign and malignant groups, employing amylase activity stain to detect the location of amylase on the gel using $7.5 \%$ acrylamide gel. According to application note $306 \mathrm{LKB}$, pre electrophoresis was carried out at $50 \mathrm{~mA}$ and $15 \mathrm{v} / \mathrm{cm}$ for $30 \mathrm{~min}$. A volume of $(10 \mu \mathrm{l})$ of the samples were applied into the wells in the gel, and concentrated for 5-10 min. with a current of $20 \mathrm{~mA}$. Electrophoresis was continued using $40 \mathrm{~mA}$, until the bromophenol blue dye reached the gel margin. Then the gel was stained for amylase activity.

The method of Laemmli (Laemmli, 1952) using 12.5\% acrylamide gel as a separating gel (containing $0.5 \mathrm{ml} 10 \%$ SDS and $0.5 \mathrm{gm}$ RNA), while $4.5 \%$ acrylamide was used as stacking gel (containing $0.3 \mathrm{ml} 10 \%$ SDS) was used to separate alkaline RNase isoenzymes in sera and saliva samples of control and patient groups, according to application note 306 LKB. Then the gel was stained for RNase activity.

Amylase activity staining (Merritt et al., 1973)

1- Phosphate buffer $(0.02 \mathrm{M}) \mathrm{pH} 6.9$ containing $0.0067 \mathrm{M} \mathrm{NaCl}$

2- Starch $1 \%(\mathrm{w} / \mathrm{v})$ in phosphate buffer

3- KI- iodine solution. This solution was prepared as follows:

$5 \mathrm{gm} \mathrm{KI}$ and $1.0 \mathrm{ml}$ of stock solution (iodin $2 \mathrm{gm} / 100 \mathrm{ml}$ and $\mathrm{KI} 6 \mathrm{gm} / 100 \mathrm{ml}$ ) then adjusted to final volume of $125 \mathrm{ml}$.

After electrophoresis, the part of the gel which contained saliva samples was incubated in starch solution for $15 \mathrm{~min}$ at room temp. followed by immediate staining with KI- iodine solution, the bands which represented amylase activity was rapidly appeared. Gel part which contained serum samples was incubated in starch solution for 2 hours at $37^{\circ} \mathrm{C}$. the gel was brief water-rinsed and stained with KI-iodine solution until resolution of the amylase banding was evident. Photographs were taken immediately after bands appearance.

Alkaline RNase activity staining (Bravo et al.,1994)

1- The incubation buffer: Tris- $\mathrm{HCl}$ buffer $(0.1 \mathrm{M} ; \mathrm{pH} 8.5)$

2- Isopropanol $10 \%(\mathrm{v} / \mathrm{v})$ in Tris buffer $10 \mathrm{mM}$ at $\mathrm{pH} 8$

3- Staining solution: toluidine blue $(0.2 \% \mathrm{w} / \mathrm{v})$ dissolved in the incubation buffer.

4- The SDS was removed from the gel with isopropanol $10 \%(\mathrm{v} / \mathrm{v})$ in Tris buffer $10 \mathrm{mM}$ at $\mathrm{pH} 8$. The gel was then incubated in the activity buffer (Tris- $\mathrm{HCl}$ buffer $0.1 \mathrm{M}$; $\mathrm{pH} 8.5$ ) for an hour to allow enzymatic digestion of the embedded substrate. The gel was stained with the staining solution for $10 \mathrm{~min}$. then the gel was destained with water until the positive bands appeared. 


\section{Statistical Analysis}

The findings were expressed as the mean \pm standard deviation. The data were analyzed with student's independent $t$ test. All statistical analyses were performed with the program Statistical Package for the Social Science (SPSS) for windows, version 10.0. A $P$ value of $<0.05$ was accepted as statistically significant.

\section{RESULTS}

The amylase activity $(\mathrm{U} / \mathrm{L})$, and specific activity $(\mathrm{U} / \mathrm{mg})$ of sera samples are presented in Table (1) and reveal a non significant difference $(\mathrm{P}>0.05)$ in both benign and malignant groups incomparison to that of the control. The specific activity results showed a non significant difference in both benign and malignant groups in comparison to that of control.

Table 1: Mean value of amylase activity and specific activity in sera of control and patient groups.

\begin{tabular}{|c|c|c|c|c|}
\cline { 4 - 5 } \multicolumn{2}{c|}{} & \multicolumn{2}{c|}{ Mean \pm SD } \\
\hline GROUP & $\begin{array}{c}\text { Sample } \\
\text { Number }\end{array}$ & $\begin{array}{c}\text { Age (year) } \\
\text { Mean } \pm \text { SD }\end{array}$ & $\begin{array}{c}\text { Activity } \\
\text { U/L }\end{array}$ & $\begin{array}{c}\text { Specific } \\
\text { Activity U/mg }\end{array}$ \\
\hline Control & 32 & $35.66 \pm 11.64$ & $331.69 \pm 70.44$ & $4.44 \pm 1.32$ \\
\hline Benign & 14 & $35.78 \pm 15.63$ & $336.37 \pm 104.89$ & $3.85 \pm 1.31$ \\
\hline Malignant & 19 & $46.57 \pm 15.21$ & $352.91 \pm 142.46$ & $3.62 \pm 1.41$ \\
\hline
\end{tabular}

The results of salivary amylase activity and specific activity were presented in Table (2), and showed a significant decrease $(\mathrm{P}<0.05)$ in amylase activity of the malignant group. The specific activity of the same group showed a highly significant decrease $(\mathrm{P}<0.001)$. Meanwhile the activity and specific activity results of benign group show non significant decrease $(\mathrm{P}>0.05)$ in comparison to that of control. 
Table 2: Mean value of salivary amylase activity and specific activity of control and patient groups.

\begin{tabular}{|c|c|c|c|c|}
\cline { 4 - 5 } \multicolumn{2}{c|}{} & \multicolumn{2}{c|}{ Mean \pm SD } \\
\hline GROUP & $\begin{array}{c}\text { Sample } \\
\text { Number }\end{array}$ & $\begin{array}{c}\text { Age (year) } \\
\text { Mean } \pm \text { SD }\end{array}$ & $\begin{array}{c}\text { Activity } \times \mathbf{1 0}^{\mathbf{3}} \\
\text { U/L }\end{array}$ & $\begin{array}{c}\text { Specific } \\
\text { Activity U/mg }\end{array}$ \\
\hline Control & 32 & $35.66 \pm 11.64$ & $1.46 \pm 0.04$ & $0.738 \pm 0.216$ \\
\hline Benign & 14 & $35.78 \pm 15.63$ & $1.34 \pm 0.36^{*}$ & $0.646 \pm 0.300^{*}$ \\
\hline Malignant & 19 & $46.57 \pm 15.21$ & $1.33 \pm 0.24^{*}$ & $0.378 \pm 0.284^{* *}$ \\
\hline
\end{tabular}

** Highly significant difference in comparison to control at $(\mathrm{P}<0.001)$.

* Significant difference in comparison to control at $(\mathrm{P}>0.05)$.

\section{$\alpha$ - Amylase Isoenzyme}

Figure (1) and Figure (2), showed the electrophoresis pattern of amylase in sera and saliva samples respectively of control and oral tumor patient groups (benign and malignant). In refer to Figure (1) the serum amylase activity located in two different parts of the gel, one with slow mobility (S-type) and the other with fast mobility (P-type), and each of them in turn consist of more than one band. Upon comparison of the amylase separation pattern there are interesting differences between the three studied groups. The isozymes in benign and malignant groups (Lane 2,3) respectively began to increase in both the slowest and the fastest fraction (according to their mobility to the anode) i.e. the pancreatic type and the salivary type were increased (number of bands and their intensity) in the sera of benign and malignant oral tumor patients in comparison to the control (Lane 1).

The salivary amylase zymogram in Figurer (2) showed several interesting differences between the three studied groups. The electrophoretic pattern for salivary amylase shows an alternating light bands and heavy bands with decreasing intensity toward the anode. Four-five bands were visualized in control group (Lane 1). These bands start in reduction (faint) in benign group (Lane 2), meanwhile, only three - four bands were detected in the malignant group (Lane 3) and they seemed to be heavy bands, i.e. the light bands disappeared in the malignant group. 


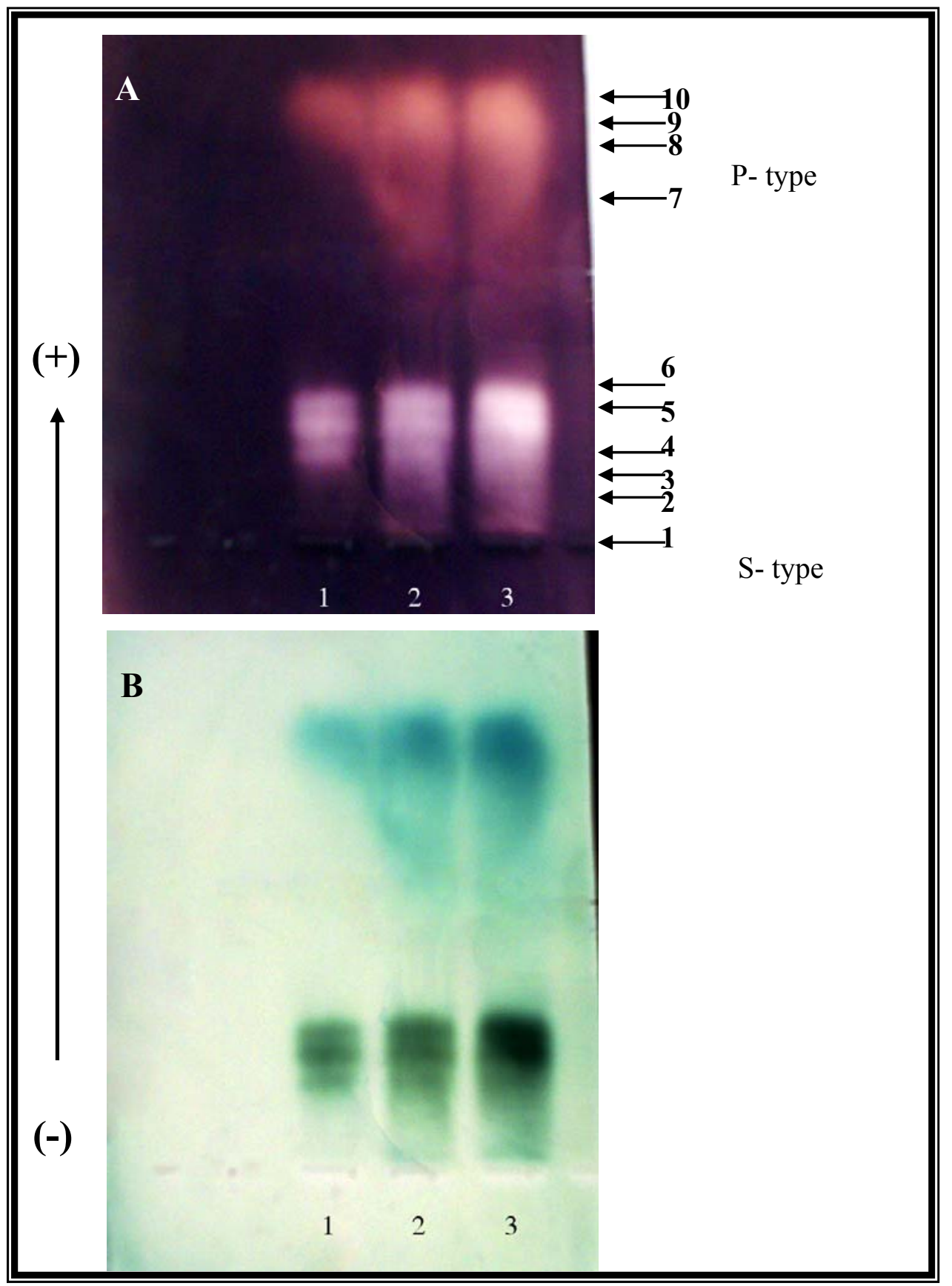

A- Positive

$B$ - Negative

Fig. 1: Conventional poly acrylamide gel electrophoresis (PAGE) 7.0\%, using Tris- glycin buffer, $\mathrm{pH} 8.9$ as electrode buffer. Electrophoresis was carried using a constant current of $40 \mathrm{~mA}$ and voltage of $15 \mathrm{v} / \mathrm{cm}$. The gel was stained for amylase activity. The samples were applied as follows:

1- crude pooled serum (control)

3 - crude pooled serum (malignant)

2- crude pooled serum (benign) 


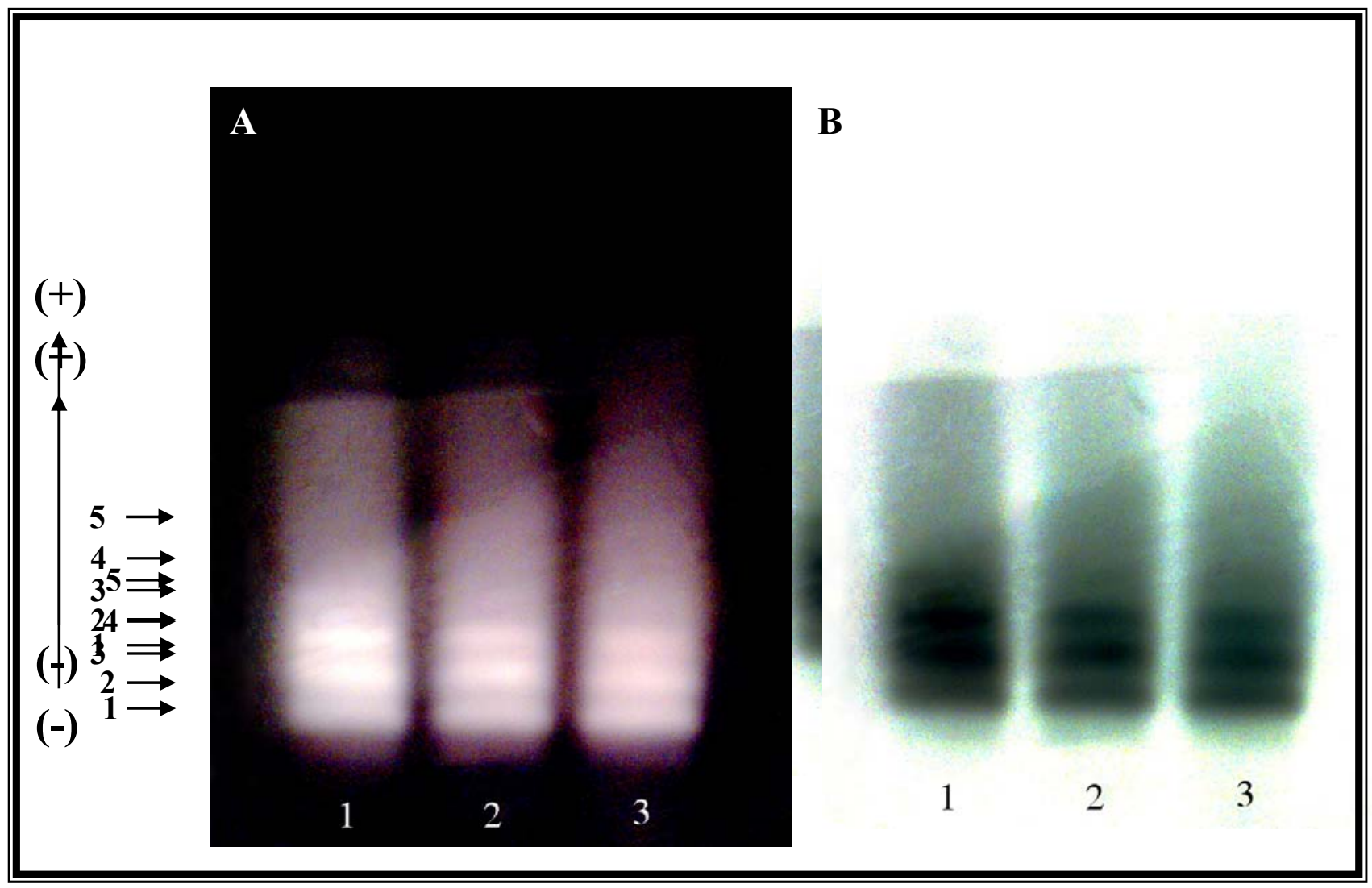

A- Positive

B- Negative

Fig. 2: Conventional poly acrylamide gel electrophoresis (PAGE) 7.0\%, using Tris- glycin buffer, pH 8.9 as electrode buffer. Electrophoresis using a constant current of $40 \mathrm{~mA}$ and voltage of $15 \mathrm{v} / \mathrm{cm}$. The gel was stained for amylase activity. The samples were applied as follows:

1 - crude pooled saliva (control)

3- crude pooled saliva (malignant)

2- crude pooled saliva (benign)

\section{Alkaline RNase activity and specific activity}

The results of sera alkaline RNase activity (U/L) and specific activity (U/mg) were presented in Table (3). These results indicated the presence of a highly significant increase $(\mathrm{P}<0.001)$ in the activity of both benign and malignant groups in comparison to that of control. The specific activity results showed also a significant increase $(\mathrm{P}<0.05)$ in both benign and malignant groups.

Table (4) presented the results of alkaline RNase activity and specific activity in saliva samples of control and oral tumor patients groups. The results reflected a non significant difference $(\mathrm{P}>0.05)$ in the activity of both benign and malignant groups, while the specific activity show a significant decrease $(\mathrm{P}=0.01)$ in malignant group and a non significant decrease $(\mathrm{P}>0.05)$ in benign group, in comparison to that of control group. 
Table 3: Mean value of alkaline RNase activity and specific activity in sera of control and patient groups.

\begin{tabular}{|c|c|c|c|c|}
\cline { 4 - 5 } \multicolumn{2}{c|}{} & \multicolumn{2}{c|}{ Mean \pm SD } \\
\hline GROUP & $\begin{array}{c}\text { Sample } \\
\text { Number }\end{array}$ & $\begin{array}{c}\text { Age (year) } \\
\text { Mean } \pm \text { SD }\end{array}$ & $\begin{array}{c}\text { Activity } \times 10^{3} \\
\text { U/L }\end{array}$ & $\begin{array}{c}\text { Specific } \\
\text { Activity } \\
\text { U/mg }\end{array}$ \\
\hline Control & 32 & $35.66 \pm 11.64$ & $18.85 \pm 3.67$ & $0.42 \pm 0.34$ \\
\hline Benign & 14 & $35.78 \pm 15.63$ & $55.97 \pm 24.64^{* *}$ & $0.62 \pm 0.24^{*}$ \\
\hline Malignant & 19 & $46.57 \pm 15.21$ & $62.08 \pm 17.65^{* *}$ & $0.65 \pm 0.16^{*}$ \\
\hline
\end{tabular}

**Highly significant difference in comparison to control at $(\mathrm{P}<0.001)$.

*Significant difference in comparison to control at $(\mathrm{P}<0.05)$.

Table 4: Mean value of alkaline RNase activity and specific activity in saliva of control and patient groups.

\begin{tabular}{|c|c|c|c|c|}
\cline { 3 - 5 } \multicolumn{2}{c|}{} & \multicolumn{2}{c|}{ Mean \pm SD } \\
\hline GROUP & $\begin{array}{c}\text { Sample } \\
\text { Number }\end{array}$ & $\begin{array}{c}\text { Age (year) } \\
\text { Mean } \pm \text { SD }\end{array}$ & $\begin{array}{c}\text { Activity } \times 10^{3} \\
\text { U/L }\end{array}$ & $\begin{array}{c}\text { Specific } \\
\text { Activity U/mg }\end{array}$ \\
\hline Control & 32 & $35.66 \pm 11.64$ & $15.60 \pm 3.89$ & $7.67 \pm 2.23$ \\
\hline Benign & 14 & $35.78 \pm 15.63$ & $15.51 \pm 9.20$ & $6.62 \pm 5.23$ \\
\hline Malignant & 19 & $46.57 \pm 15.21$ & $15.84 \pm 7.27$ & $4.27 \pm 2.61^{*}$ \\
\hline
\end{tabular}

*Significant difference in comparison to control at $(\mathrm{p} \leq 0.01)$.

\section{Acid RNase activity and specific activity}

The results of sera acid RNase activity (U/L) and specific activity (U/mg) were presented in Table (5) and reflect a non significant difference $(\mathrm{P}>0.05)$ in both activity and specific activity of benign and malignant groups in comparison to that of the control group. The results in Table ( 6) showed the activity and specific activity of acid RNase in saliva of the three studied groups, and reveal a non significant difference ( $\mathrm{P}>0.05)$ in both activity and specific activity of benign and malignant groups in comparison to that of control. 
Table 5: Mean value of acid RNase activity and specific activity in sera of control and patient groups.

\begin{tabular}{|c|c|c|c|c|}
\cline { 3 - 5 } \multicolumn{2}{c|}{} & \multicolumn{2}{c|}{ Mean \pm SD } \\
\hline GROUP & $\begin{array}{c}\text { Sample } \\
\text { Number }\end{array}$ & $\begin{array}{c}\text { Age (year) } \\
\text { Mean } \pm \text { SD }\end{array}$ & $\begin{array}{c}\text { Activity } \times 1 \mathbf{1 0}^{\mathbf{3}} \\
\text { U/L }\end{array}$ & $\begin{array}{c}\text { Specific } \\
\text { Activity } \\
\text { U/mg }\end{array}$ \\
\hline Control & 32 & $35.66 \pm 11.64$ & $17.42 \pm 4.27$ & $0.34 \pm 0.22$ \\
\hline Benign & 14 & $35.78 \pm 15.63$ & $24.96 \pm 14.89$ & $0.30 \pm 0.19$ \\
\hline Malignant & 19 & $46.57 \pm 15.21$ & $24.65 \pm 17.65$ & $0.30 \pm 0.20$ \\
\hline
\end{tabular}

Table 6: Mean value of acid RNase activity and specific activity in saliva of control and patient groups.

\begin{tabular}{|c|c|c|c|c|}
\cline { 3 - 5 } \multicolumn{2}{c|}{} & \multicolumn{2}{c|}{ Mean \pm SD } \\
\hline GROUP & $\begin{array}{c}\text { Sample } \\
\text { Number }\end{array}$ & $\begin{array}{c}\text { Age (year) } \\
\text { Mean } \pm \text { SD }\end{array}$ & $\begin{array}{c}\text { Activity } \times \mathbf{1 0}^{\mathbf{3}} \\
\text { U/L }\end{array}$ & $\begin{array}{c}\text { Specific } \\
\text { Activity } \\
\text { U/mg }\end{array}$ \\
\hline Control & 32 & $35.66 \pm 11.64$ & $5.98 \pm 2.20$ & $4.17 \pm 1.47$ \\
\hline Benign & 14 & $35.78 \pm 15.63$ & $8.30 \pm 6.65$ & $4.01 \pm 3.20$ \\
\hline Malignant & 14 & $46.57 \pm 15.21$ & $6.60 \pm 5.59$ & $2.64 \pm 3.21$ \\
\hline
\end{tabular}

\footnotetext{
Alkaline RNase isoenzymes

Figure (3) and Figure (4) showed the electrophoresic patterns of the protein and RNase activity respectively of sera and saliva samples among the studied groups. Figure (4) showed that the enzyme present in different forms in sera samples of the studied groups. Reflect the different sources of this enzyme in the sera. These forms were different in their relative mobilities, most of them were with relatively low mobility on the gel. Also the electrozymogram showed that there were RNase's bands with different intensities that moved faster than the others in all sera samples which reflected changes in their molecular weight and charges. When enzyme activity was localized on the gel for the saliva samples, Figure (4) showed that the enzyme presented in one form in saliva samples of each group with different mobility in the gel.
} 


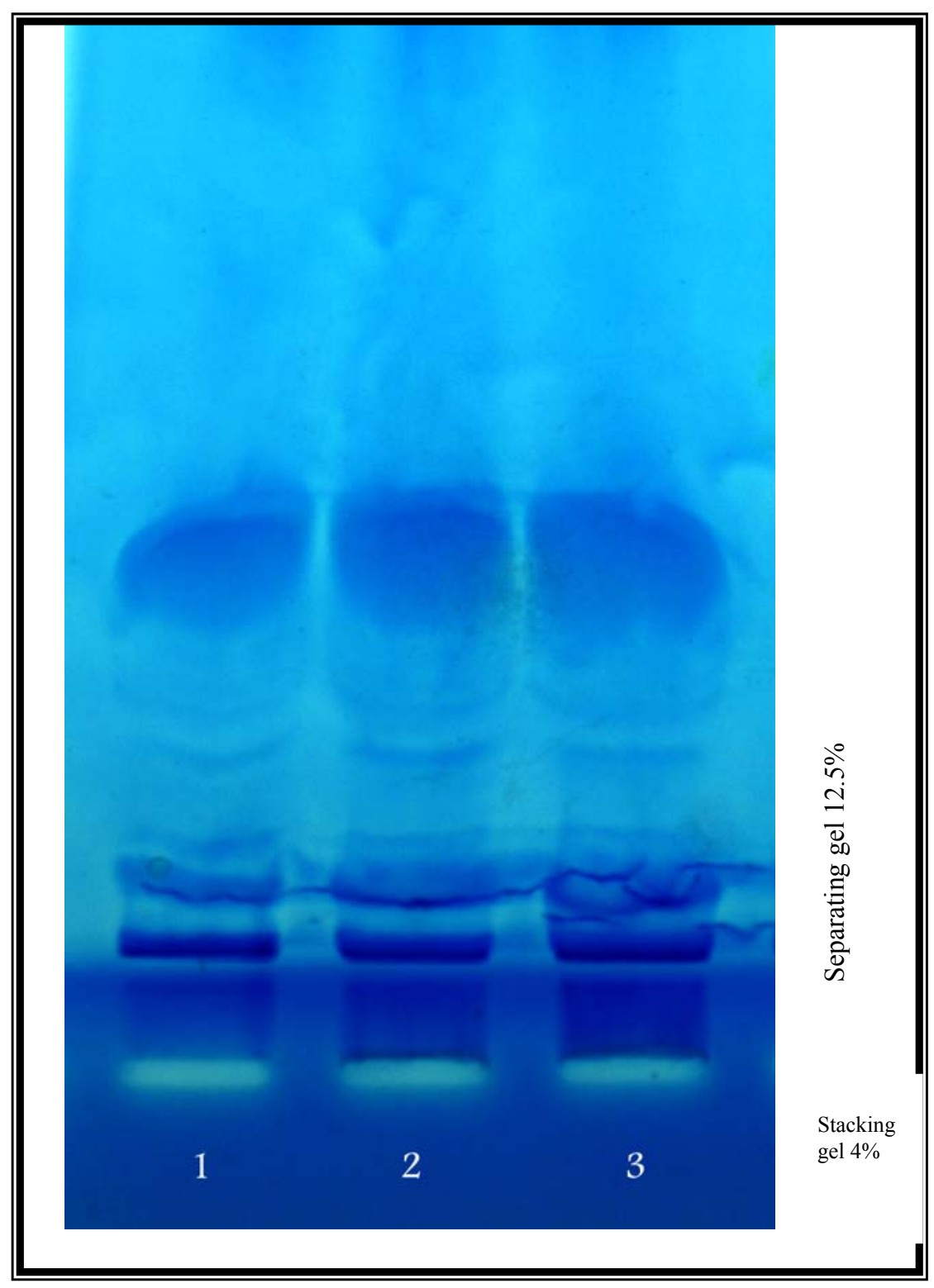

Figure 3: Conventional poly acrylamide gel electrophoresis $12.5 \%$, using tri-glycin $\mathrm{pH} 8.2$ as electrode buffer. The gel was stained for protein. The samples used were as follows: 1 - pooled crude serum (control)

2- pooled crude serum (benign)

3 - pooled crude serum (malignant) 
Study of some Hydrolytic Enzymes..........

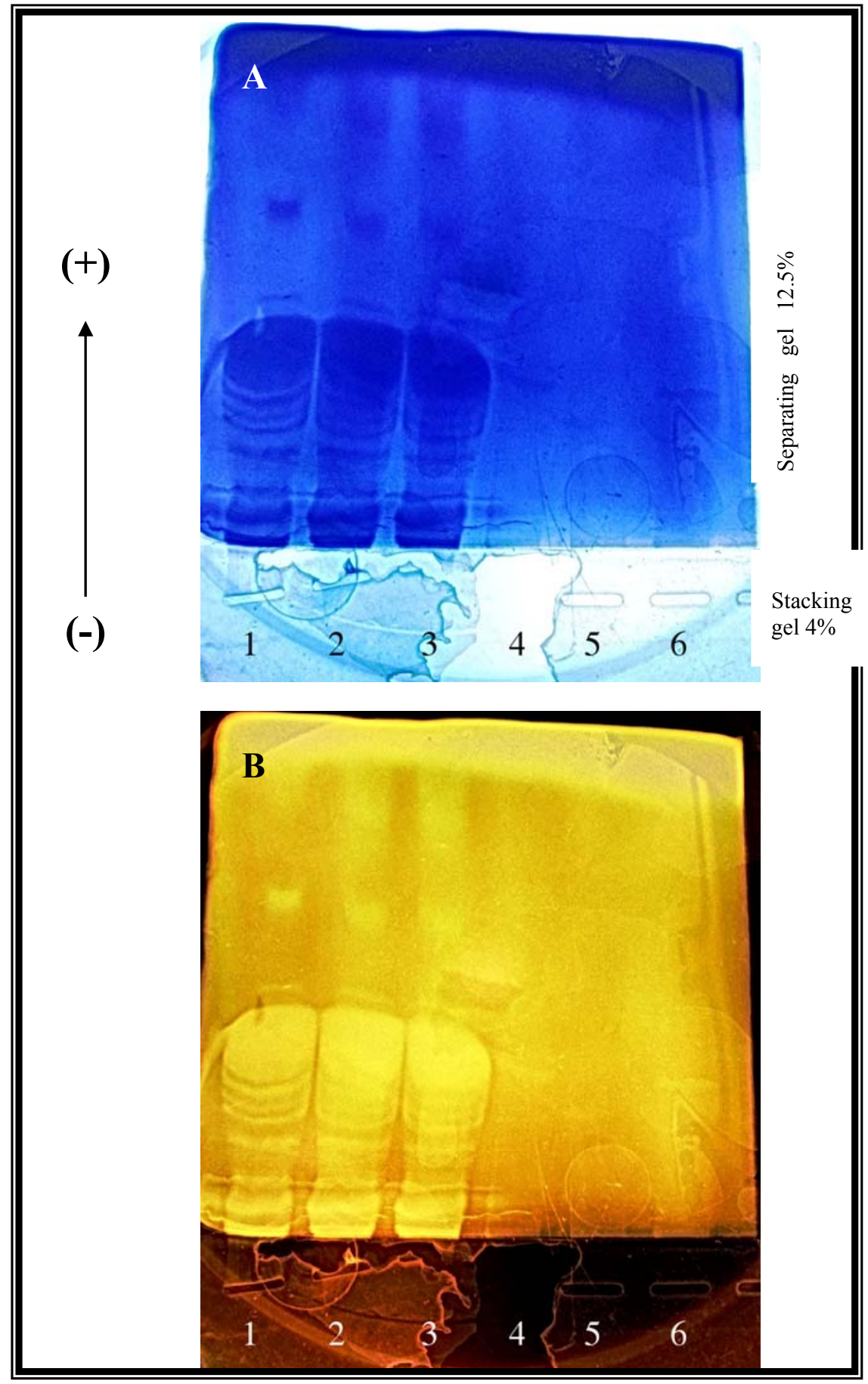

A- Positive

B- Negative

Fig. 4: Conventional poly acrylamide gel electrophoresis $12.5 \%$, using tri-glycin pH 8.2 as electrode buffer. The gel was stained for alkaline RNase activity. The samples used were as follows:

1 - pooled crude serum (malignant)

2- pooled crude serum (benign)

3 - pooled crude serum (control)
4- pooled crude saliva (control)

5- pooled crude saliva (benign)

6- pooled crude saliva (malignant) 


\section{DISCUSSION}

Hyperamylasemia has been reported to occur in many malignancies such as lung, pancreas, and to a lesser extent ovary (Yokoyama et al., 1977, Warshaw et al., 1977) and also with multiple myeloma (Pinlli et al., 2006). The alpha amylase present in sera samples actually is the total amylase i.e. consists of both P-type and S-type. Therefore the elevation of sera alpha amylase (total amylase) may be attributed to the S-type that is present within the sera alpha amylase, which secreted from variety of tissues. Therefore the elevation of sera amylase (total amylase) may not only occur in pancreatic disorders (referred to elevated P-type), but also in mumps, intestinal obstruction and other intestinal disorders and also in cases of malignancies. In addition to its well- known function as a digestive enzyme, salivary alpha amylase has been reported to act as an antimicrobial enzyme (Tenovuo, 1998) and interacts specifically with certain oral bacteria and may play a role in modulating the adhesion of those species to teeth (Scannapieco et al., 1993). In the current study, salivary amylase activity showed a significant decrease in oral tumor patient groups in comparison to that of the control group. This result is in agreement with other (Shpitzer et al., 2007) on their study on Oral Squamous Cell Carcinoma (OSCC) patients and disagrees with Bssalyk (Bassalyke et al., 1992) where they observed a significant increase in salivary alpha amylase in patient with malignant tumors of the oral mucosa. . It has been suggested that amylase make up about $1 / 3$ of the total protein content in parotid saliva (Pederson et al., 2002) so amylase is thought to be an indicator of acinar cell function in parotid glands (Rantoneu, 2003). It has been found earlier that amylase increases with saliva flow rate, and it is generally considered to be a reliable marker of serous cell function (Almstahl, 2001). The observed reduced amylase activity in this study may be due to the low salivary flow rate noticed in almost all the patients under the present study. The altered concentration and activity of various enzymes, electrolytes, and ions in saliva may compromise various salivary functions, so the reduced salivary amylase activity may impair salivary digesting ability (Shpitzer et al., 2009) and indicate dysfunction in parotid glands.

The separation of amylase isoenzymes by gel electrophoresis has been shown to be reliable and reproducible (Rantoneu, 2003). The differences in sera and saliva amylase activity was confirmed by the elecrtophoretic profile (Figure 1) and (Figure 2) respectively, where it showed that the sera amylase consist of P-type and S-type which they differ in their mobility toward the anode. The increased isozymes referred to the secretion of S-type from variety of tissues including malignant one. Salivary amylase zymogram showed a decreased in bands number and intensity in benign and malignant groups when compared with the control group, and this may due to the dysfunction of parotid gland which is the major source of salivary alpha amylase in the saliva.

Throughout this study, acid and alkaline RNases activities were measured in sera and saliva samples of control and oral tumor patient groups. The results reveal that oral tumor patient groups have highly significant increased RNase activity in sera samples. The observed increased in sera alkaline RNase is in agreement with many other studies in different kinds of cancer such as ovarian cancer (Al-Shaikhly, 2004), pancreatic cancer(Ester, 2000), , and uterine cancer(Al-Shamarre, 2002). It have been suggested by a number of authors that the levels of 
RNase activity in human body fluids, such as serum, urine, and saliva may be an indicative of disease states (Park et al., 2006). Generally it is known that cancer cells are characterized by uncontrolled increase in the number and size (Sano et al., 2007), which mean that there will be an increase in the synthesis of different proteins and this explain the need for high RNase activity. Although many human tissues express ribonucleases, the origin of the serum RNase has not been established (Tran et al., 2007). The increase in RNase activity may be attributed to many reasons such as the lack of host defense mechanisms, or it may be produced by malignant cells, a secondary destructive process in other cell or tissue, and this is confirmed by the appearance of different bands on the gel which have different mobilities in the acrylamide gel.

RNase activity in saliva during this study was also investigated, and the results revealed a non significant increase in RNase activity. There are some reports on human RNase which indicate the presence of an elevation in the activity of this enzyme in saliva of patients with different diseases such as cystic fibrosis (CF) (Bardon, 1980), influenza, ovarian and breast tumors (Al-Shaikhly, 2004). Actually little is known about human salivary RNases and its molecular nature and properties (Li et al., 2004). Saliva is known to contain ribonucleases from various sources (Westra et al., 2004). It is not clear how RNA and RNase can coexist in the saliva, RNA can enter the oral cavity through various routes, including saliva secretions from the three major salivary glands and minor glands, like many micro and macro molecules, RNA in salivary glands secretions could originate from acinar cells (Aps et al., 2005), or from Gingival Crevice Fluid (GCF). Many blood cells and their cellular components are released into the oral cavity from GCF (Delima et al., 2000), or from desquamated oral epithelial cells, where turnover of epithelial cells in the oral cavity could be another source of RNA (Hu, 2006). Also micro wounds inside the oral cavity could release the RNA directly from the blood (Park et al., 2006). The cause of such elevation in activity may be attributed to the alteration in cell permeability of tumor cell membranes where a number of changes in the biochemical characteristic of malignant cell surface have been observed. Such changes lead to transport of enzymes from the blood to the saliva via salivary glands, and one of these enzymes is RNases. Furthermore, some divalent cations or other parameters that activated the RNase may be transported from the blood to the saliva with the disease such as cystic fibrosis (Bardon, 1980), and this increase in their level in saliva, may lead to the observed elevation in salivary RNase. Salivary RNA is protected from degradation by the association with macromolecules (Park et al., 2006). Saliva contains mucin (proteins that forms oligomers which are highly glycosylated) (Lamblin et al., 2001), and it is possible that in saliva some RNA is protecting from degradation by their association with these oligomers. This may be the reason for the reduction of salivary RNase specific activity. The electrophoretic profile of RNase in sera and saliva samples Figure (4) reflect the increase in RNase activity in the oral tumor patient groups, where it is obvious the presence of increased isoenzymes in benign and malignant groups and also these isoenzymes (forms) are different in their mobility in the gel, that mean different in their molecular weight. 


\section{REFERENCES}

Almstahl, A.; Wikstrom , M.; Groenink, J. (2001). Lactoferrin, amylase and mucin MUC5B and their relation to the oral microflora in hyposalivation of different origin. Oral Microbiol. Immunol. 46, 345-352.

Al-Shaikhly, O. R. (2004). Influence of ovarian tumors on some biochemical parameters. M.Sc. Thesis, College of Science Baghdad University.

Al-Shamarre, S. A. (2002). Some biochemical aspects in women patient with benign and malignant cervix and uterin tumors. Ph.D. Thesis, College of Science, Baghdad University.

Amerongen, A. V.; Ligtenberg, A. J.; Veerman, E. C. (2007). Implications for diagnostics in the biochemistry and physiology of saliva. Ann. N. Y. Acad. Sci. , 1098(1) , 1-6.

Aps, J.K. ; Martens , L.C. (2005). The physiology of saliva and transfer of drugs into saliva. Forensic Sci. Int . 150,119-131.

Bardon, A.; Shugar, D. (1980). Properties of purified salivary ribonuclease and salivary ribonuclease levels in children with cystic fibrosis and in heterozygous carriers. Clin Chim Acta. Feb14, 101(1), 17-24.

Bassalyk, L. S.; Guskova, N.K.; Pushintseva, L.P.; Linbimova, N.V. (1992). Enzyme and isoenzyme activity in patients with malignant tumors of the oral mucosa. Vopr. Onkol. 38(3), 291-299.

Blank, A.; Dekker, C.; Scfaeieven, G.; Sugiyama, R.; Thelen, M. (1989). Human body fluid RNases; detection, interrelationship and significance. Nucleic Acids Symp. Ser., 10, 203-207.

Bravo, J.; Fernandez , E.; Ribo, M.; Liorense, R.; Cuchillo, C.M. (1994). Aversatile negative - staining ribonuclease zymogram. Anal. Biochem. 219, 82-86.

Caraway, W. T. (1969). A stable starch substrate for determination of amylase in serum and other body fluids. Am. J. Clin. Path. 32(1), 97-99.

Davis, M.T. (1958). A universal buffer solution for use in ultra- violet spectrophotometry Biochemistry . 84, 284-251.

Delima, H.J.; Van Dyke, T.E., (2000). Origin and function of the cellular components in gingival crevice fluid. Periodontal. 31, 55-76.

Ester, F.; Rosa, P.; Marsha, L.; Rafael, D. (2000). Ribonucleases expressed by human pancreatic adenocarcinoma cell lines. Eur. J. Biochem. 267,1484-1494.

Hartree, E.E. (1972). Determination of protein: A modification of the Lowry method that gives a linear photometric reasponse. Anal. Biochem. 48, 422-427.

Hu, S.; Li, Y.; Wang, J.; Zhou, X. (2006). Human saliva proteome and transcriptome. J. Dent. Res. $85,1129-33$.

Jianzhi, Z. ; Kimberly, D.; Helen, F. (2003). Human RNase 7: a new cationic ribonuclease of the RNase A superfamily. Nucleic Acid Research. 31, 602-607.

Jochen, P.; Sonja, B.; Birgit, S.; Ingma, H.; Gunter, J.; Hans-Georg, R.; Steve, P. (2006). Characterization of the ribonuclease activity on the skin surface. Genetic Vaccines and Theray. 4, 1-17. 
Kantola, S.; Parikka , M.; Jokinen, K.; Hyrynkangs, K.; Soini, Y.; Alho, O.P.; Salo, T. (2000. Prognostic factors in tongue cancer-relative importance of demographic, clinical and histopathological factors. Br. J. Cancer . 83, 614-619.

Kaufman, E.; Lamster , I. (2002). The diagnostic applications of saliva. Cri. Rev. Oral. Biol. Med. 13(2), 197-212.

Lac, G. (2002). Saliva assay in clinical and research biology. Pathol. Biol. 49(8), 660-7.

Laemmli, U.K. (1952). Cleavage of structural proteins during the assembly of the head of bectriophage $\mathrm{T}_{4}$. Nature. 227, 680-686.

Lamblin, G.; Degroote, S.; Perini, J.M.; Delmatte, P.; Scharfman , A.; Davril , M.; (2001). Human airway mucin glycosylation: a combinatory of carbohydrate determinants which vary in cystic fibrosis. Glycoconj, 18, 614-619.

Li, Y.; Zhou, X.; St. John, M.A.; Wong, D.T. (2004). RNA profiling of cell free saliva using micro-array technology. J. Dent. Res. 83, 199-203.

Mavazesh, M. (1993). Methods for collecting saliva. Ann. Ny. Acad. Sci. 20, 72-77.

Merrit, A. D.; Karn, R. C. (1977). The human a-amylase. Adv. Hum. Genet. 8,195-234

Nagler, R.; Bahar, G.; Shpitzer, T. Feinmesser, R. (2006). Concomitant analysis of salivary tumor markers - a new diagnostic tool for oral cancer. Clin. Cancer Res. 12, 397984.

Noble, R.E. (2000). Salivary $\alpha$-amylase and lysozyme levels: A non-invasive technique for measuring parotid vs submandibular / sublingual gland activity. J. Oral. Sci. 42,82-86.

Park, N.J.; Li, Y.; Ya, T.; Brinkman, B.M.; Wong, D.T. (2006). Molecular diagnostics and genetics Characterization of RNA in saliva. Clinical Chem. 52(6), 988-994.

Pederson, A.M.; Bandow, A.; Beier-Jensen, S. (2002). Saliva and gastrointestinal function of taste mastication, swallowing and digestion. Oral Diseases. 8,117-125.

Pinlli, M.; Bindi, M.; Rosada, J.; Castiglioni, P.S. (2006). Amylase: A disease activity index in multiple myeloma? Leukemia and Lymphoma, 47(1), 154.

Raines, R. (1998). Ribonuclease A .Chem. Rev. 98,1045-1065.

Rantoneu, P. (2003). "Salivary Flow and Composition in Healthy and Diseased Adults". Academic Dissertation, University of Helsinki /Finland.

Sano, D.; Myers, J.N. (2007). Metastasis of sequamous cell carcinoma of the oral tongue. Cancer Metastasis Rev. 26, 645-62.

Scannapieco, F.A.; Torres, G.; Levine, M.J. (1993). Salivary $\alpha$ - amylase: role in dental plaques and caries formation. Crit. Rev. Oral Biol. Med. 4, 301-307.

Shpitzer, T.; Bahar, G.; Feinmesser, R.; Nagler, R.M. (2007). A comprehensive salivary analysis for oral cancer diagnosis. J. Cancer Research and Clinical Oncology.

Shpitzer, T.; Hamzany, Y.; Bahar , G.; Feinmesser, R.; Savulescu, D. (2009). Salivary analysis of oral cancer biomarkers. Br. J. Cancer. 6(7), 1194-1198.

Tenovuo, J. (1998). Antimicrobial function of human saliva-how important is it for oral healthy? Acta. Odontol Scand. 50, 250-256.

Tran, N.; Mclean, T.; Zhang, X.; Zhao, C.J. Thomson, J.M.; Obrien, C.; Rose, B. (2007). Micro RNA expression profiles in head and neck cancer cell lines. Biochem. Biophys. Res. Commun. 358,12-7. 
Warshaw, A.L.; Lee, K.H. (1977). Characteristic alternations of serum isoenzymes of amylase in disease of liver, pancreatic, salivary glands, lung and genitalia. J. Surg. Res. 22, 362-369.

Westra, W. H.; Califona, J. (2004). Toward early cancer detection using gene expression of saliva: a through fore or dead end? Clin. Cancer Res. 10, 8130-8131.

Yokoyama, M.; Natsuizaka, T.; Ishir, Y.(1977). Amylase-producing lung cancer. Ultra structure and biochemical studied. Cancer. 40, 766-772. 